\title{
Calyculin A induces apoptosis and stimulates phosphorylation of p65NF-kB in human osteoblastic osteosarcoma MG63 cells
}

\author{
HIROAKI TANAKA ${ }^{1,2}$, KAYA YOSHIDA ${ }^{1}$, HIROHIKO OKAMURA ${ }^{1}$, \\ HIROYUKI MORIMOTO $^{3}$, TOSHIHIKO NAGATA ${ }^{2}$ and TATSUJI HANEJI $^{1}$ \\ Departments of ${ }^{1}$ Histology and Oral Histology, ${ }^{2}$ Periodontology and Endodontology, \\ Institute of Health Biosciences, The University of Tokushima Graduate School, Kuramoto, \\ Tokushima 770-8504; ${ }^{3}$ Department of Anatomy, School of Medicine, \\ University of Occupational and Environmental Health, Kitakyushu 807-8555, Japan
}

Received February 26, 2007; Accepted April 13, 2007

\begin{abstract}
Previously, we reported that okadaic acid, a specific inhibitor of serine/threonine protein phosphatases, induced apoptosis in human osteoblastic cells. However, it is not clear whether calyculin A, another inhibitor of protein phosphatases, would induce apoptosis in human osteoblastic cells and if so, which mechanisms are involved and whether the phosphorylation status of NF- $\mathrm{\kappa B}$ could be affected by the treatment with calyculin A. In this report, we demonstrate that calyculin A induced apoptosis in MG63 cells, as judged by WST-8 assay, nuclear fragmentation, and DNA ladder formation. Expression of PTEN, FasL, and FasR mRNA was stimulated by calyculin A treatment in MG63 cells. Calyculin A also enhanced the phosphorylation level of NF- $\mathrm{KB}$, as judged from the results of Western blot analysis and an in vitro dephosphorylation assay. Western blot analysis with anti-

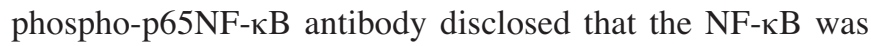
phosphorylated on serine 536 in cytosol and translocated into nucleus with calyculin A-treatment. The phosphorylation status of p65NF- $\mathrm{BB}$ was further confirmed by using the phosphorylation site-mutated $\mathrm{p} 65 \mathrm{NF}-\kappa \mathrm{B}$ gene transfected into HEK293 cells. Unlike TNF- $\alpha$, calyculin A treatment did

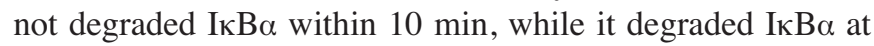
2-h treatment. Our findings indicate that calyculin A elicit phosphorylation of $\mathrm{NF}-\kappa \mathrm{B}$ on serine 536 in MG63 cells, resulting in the translocation of phospho-NF- $\mathrm{B}$ to the nucleus, thereby promoting transcriptional activity of NF-кBrelated genes.
\end{abstract}

Correspondence to: Dr Tatsuji Haneji, Department of Histology and Oral Histology, Institute of Health Biosciences, The University of Tokushima Graduate School, 3-18-15 Kuramoto, Tokushima 770-8504, Japan

E-mail: tat-hane@dent.tokushima-u.ac.jp

Key words: apoptosis, calyculin A, NF-кB, phosphorylation, phosphatase

\section{Introduction}

Apoptosis is an important and well-controlled form of selfregulated cell death that plays a major role during embryogenesis, carcinogenesis, cancer treatment, and immune and toxic cell killing $(1,2)$. Apoptosis can be regulated by extrinsic factors, including hormones, growth factors, cell-surface receptors, and various forms of cellular stress. The action of apoptosis-related factors is often affected by the modulation of the phosphorylation status of key elements active in the apoptotic processes (3).

Nuclear factor-kappa B (NF-кB) is an essential transcription factor in the control of expression of genes involved in cell growth, differentiation, inflammation, and neoplastic transformation (4-6). NF- $\mathrm{KB}$ has also been shown to have a role in regulating the apoptotic program, either as essential for the induction of apoptosis or as a blocker of apoptosis (7-11). $\mathrm{NF}-\kappa \mathrm{B}$ is present in the cytoplasm as two major precursor forms, either as the p50-p65 complex with the inhibitor of $\kappa \mathrm{B} \alpha(\mathrm{I} \kappa \mathrm{B} \alpha)$ or as p65-p105 complex. For activation of NF-кB, $\mathrm{I} \kappa \mathrm{B} \alpha$ is phosphorylated, ubiquitinated, and then degraded by the proteasome, thereby allowing translocation of the liberated $\mathrm{NF}-\kappa \mathrm{B}$ from the cytoplasm to the nucleus. In the nucleus, $\mathrm{NF}-\kappa \mathrm{B}$ regulates the expression of the target genes that modulate biological responses. Several kinases and phosphatases are considered as candidate enzymes for involvement in the phosphorylation of NF-кB (12-14). However, whether and, if so, how phosphorylation of NF- $\mathrm{B}$ modulates its function remains unclear.

Calyculin A (CA) and okadaic acid (OA) are potent inhibitors of protein phosphatases type 1 (PP1) and type 2A (PP2A), which dephosphorylate serine and threonine residues in eukaryotic cells $(15,16)$. The use of these agents has led to the understanding that the phosphorylation and dephosphorylation status is related to cellular regulation including apoptosis (17-20). We recently reported that the doublestranded RNA-dependent protein kinase (PKR) was activated and $\mathrm{NF}-\kappa \mathrm{B}$ translocation occurred during the OA-induced apoptosis $(20,21)$. However, the mechanisms whereby CA acts on apoptosis were not studied in detail. In the present study, we examined whether CA could induce apoptosis in 
human osteoblastic MG63 cells. We also examined the effect of $\mathrm{CA}$ on the phosphorylation status of $\mathrm{NF}-\kappa \mathrm{B}$ in MG63 cells. Our results indicate that the CA treatment induced apoptosis in MG63 cells and enhanced the phosphorylation status of serine residue positioned at 536 in $\mathrm{p} 65 \mathrm{NF}-\mathrm{\kappa B}$ in these cells.

\section{Materials and methods}

Materials. CA and OA were purchased from Wako Chemicals (Osaka, Japan), and stock solutions $(100 \mu \mathrm{M})$, prepared in dimethyl sulfoxide and protected from light, were diluted to the appropriate concentrations with medium. TNF- $\alpha$ was purchased from Sigma Chemicals (St. Louis, MO, USA). Fetal bovine serum (FBS) was obtained from JRH Biosciences (Lenexa, KS, USA); and $\alpha$-modified Eagle's minimal essential medium $(\alpha-\mathrm{MEM})$ and Dulbecco's modified Eagle's minimum essential medium (D-MEM) from Gibco BRL (Gaithersburg, MD, USA). Plastic dishes were from Iwaki (Chiba, Japan). Anti-p65NF-кB and anti-Eps15 antibodies were purchased from Santa Cruz Biotechnology (Santa Cruz, CA, USA). Anti-phospho-p65NF-кB (Ser536) and anti-phospho-p65NF$\kappa \mathrm{B}$ (Ser276) antibodies were obtained from Cell Signaling Technology (Danvers, MA, USA). Anti-phospho-p65NF-кB (Ser529) and $\mathrm{I} \kappa \mathrm{B} \alpha$ antibodies were obtained from BD Biosciences (Palo Alto, CA, USA). Anti-Lamin B1 antibody was from Zymed Laboratories (South San Francisco, CA, USA). Other materials used were of the highest grade commercially available.

Cell culture. Human osteosarcoma MG63 cells and human embryonic kidney HEK293 cells were obtained from the American Type Culture Collection (Rockville, MD, USA). The MG63 cells and HEK 293 cells were cultured in $\alpha$-MEM and D-MEM, respectively supplemented with $10 \%(\mathrm{v} / \mathrm{v})$ FBS, $2 \mathrm{mM}$ glutamine, $100 \mathrm{U} / \mathrm{ml}$ penicillin, and $100 \mu \mathrm{g} / \mathrm{ml}$ streptomycin and maintained at $37^{\circ} \mathrm{C}$ in a humidified atmosphere of $5 \% \mathrm{CO}_{2}$ and $95 \%$ air. The medium was replenished every 3 days. Confluent cells were treated with various concentrations of reagents for variable periods of time. Cell modification was monitored with the use of an Olympus IMT-2 phase-contrast microscope.

WST-8 assay. The cytotoxicity of MG63 cells was analyzed by the WST-8 quantitative colorimetric assay for cell survival (Dojindo Laboratory, Kumamoto, Japan). The assay detects living cells and the generated signal depends on the degree of activation of the cells. MG63 cells grown in 96-well culture plates were treated with the agents for various time periods and washed once with medium. Ten $\mu 1$ of the reaction solution was immediately added to $100 \mu \mathrm{l}$ of a culture medium per well and the cells were then incubated for an additional $90 \mathrm{~min}$ at $37^{\circ} \mathrm{C}$ in a humidified atmosphere of $5 \% \mathrm{CO}_{2}$ and $95 \%$ air. The absorbance of each sample was measured at $450 \mathrm{~nm}$ with an ImmunoMini NJ-2300 microplate reader (Japan Intermed, Tokyo, Japan). Data were expressed as mean \pm SEM. The statistical significance was determined using the Student's t-test calculated by Microsoft Excel (Microsoft, Redmond, WA, USA). The level of significance was set at $\mathrm{P}<0.01$.
Nuclear fragmentation assay with Hoechst staining. The cells were plated on sterile $18-\mathrm{mm}$ round glass coverslips placed in $60-\mathrm{mm}$ plastic dishes and cultured. After appropriate incubation with $\mathrm{CA}$, the coverslips were removed from the dishes and placed directly into $10 \%$ formalin in PBS for $10 \mathrm{~min}$ at ambient temperature. The fixed cells were washed three times with PBS and permeabilized with methanol for $10 \mathrm{~min}$ at $-20^{\circ} \mathrm{C}$. After washing three times with PBS the coverslips were incubated with Hoechst $33342(10 \mu \mathrm{g} / \mathrm{ml})$ for $10 \mathrm{~min}$ at ambient temperature, rinsed with PBS, and the coverslips were mounted while wet in aqueous mounting medium (Biomeda, Foster City, CA, USA). Cells were examined under an Olympus BX50 microscope equipped for epifluorescent illumination (BX-FLA). Photomicrographs were recorded on digital equipment (Olympus, DP70-WPCXP).

DNA isolation and agarose gel electrophoresis. Cells were washed twice in PBS followed by lysis in cold $10 \mathrm{mM}$ Tris- $\mathrm{HCl}$ buffer (pH 7.5), 10 mM EDTA, and 0.5\% Triton X-100. After cell lysis, debris was removed by centrifugation at 15,000 $\mathrm{g}$ for $20 \mathrm{~min}$. DNase-free RNase was added to the lysates at a final concentration of $20 \mu \mathrm{g} / \mathrm{ml}$, and incubated for $1 \mathrm{~h}$ at $37^{\circ} \mathrm{C}$ with gentle shaking, followed by the addition of Proteinase $\mathrm{K}$ at a final concentration of $20 \mu \mathrm{g} / \mathrm{ml}$ for another $1 \mathrm{~h}$ at $37^{\circ} \mathrm{C}$. DNA was precipitated with $50 \%$ 2-propanol and $0.5 \mathrm{M} \mathrm{NaCl}$ overnight at $-20^{\circ} \mathrm{C}$. After centrifugation and drying, the DNA was dissolved in TE-buffer (10 mM Tris, $\mathrm{pH} 8.0$, containing $1 \mathrm{mM}$ EDTA). Agarose gel electrophoresis of DNA was performed through a $2.0 \%$ agarose gel. DNA markers (100 bp) (New England BioLabs, Beverly, MA, USA) were run in the same gels. The gels were stained for $10 \mathrm{~min}$ with $10 \mu \mathrm{g} / \mathrm{ml}$ ethidium bromide. To visualize apoptotic alterations to DNA integrity, we observed the DNA bands on a UV transilluminator (Vilber Lourmat, Marnela Vallee, France). Photographs were taken with a Polaroid DS-300 camera.

$R N A$ preparation and $R T-P C R$. After the appropriate treatment, total cellular RNA was isolated from MG63 cells using Isogen (Nippon Gene, Tokyo, Japan). The purified RNA was further incubated with DNase I to digest the contaminating DNA followed by phenol extraction and ethanol precipitation. cDNA was synthesized by using Ready-To-Go RT-PCR Beads (Amersham Pharmacia Biotech, Uppsala, Sweden). PCR was performed on the cDNA with AmpliTaq Gold ${ }^{\circledR}$ DNA Polymerase, LD (Applied Biosystems, Foster City, CA, USA) and the following primers: PTEN (forward) 5'-ACCGCC AAATTTAATTGCAG-3'; PTEN (reverse) 5'-GGGTCCTG AATTGGAFFAAT-3'. FasL (forward) 5'-TCTCAGACGTT TTTCGGCTT-3'; FasL (reverse) 5'-AAGACAGTCCCCCTT GAGGT-3'. FasR (forward) 5'-CAAGGGATTGGAATTGA GGA-3'; FasR (reverse) 5'-GACAAAGCCACCCCAAG TTA-3'. GAPDH (forward) 5'-ACCACAGTCCATGCCAT CAC-3'; GAPDH (reverse) 5'-TCCACCACCCTGTTGCT GTA-3'.

After denaturation and activation of the enzyme at $95^{\circ} \mathrm{C}$ for $10 \mathrm{~min}$, PCR amplification was performed under the following condition: $94^{\circ} \mathrm{C}$ for $50 \mathrm{sec}, 55^{\circ} \mathrm{C}$ for $50 \mathrm{sec}$, and $72^{\circ} \mathrm{C}$ for $50 \mathrm{sec}$, for total cycles indicated. The reaction was terminated after a 5-min elongation step at $72^{\circ} \mathrm{C}$. PCR products were analyzed on $2 \%$ agarose gels, stained with ethidium 
bromide, and visualized with a UV illuminator following ethidium bromide staining. Photographs were taken with a Polaroid DS-300 camera.

SDS-PAGE and Western blotting. Cultured cells were washed twice with phosphate-buffered saline (PBS), scraped into lysate buffer containing $1 \mathrm{mM}$ DTT, $1 \mathrm{mM}$ PMSF, $1 \mu \mathrm{g} / \mathrm{ml}$ leupeptin, $2 \mu \mathrm{g} / \mathrm{ml}$ aprotinin, $5 \mathrm{mM}$ EGTA, and protein phosphatase inhibitor cocktails (Sigma) in PBS. Nuclear and cytosol fractions were obtained from the cells by using a CelLytic NuCLEAR extraction kit (Sigma). The protein concentration was evaluated by using Protein Assay Reagent (Bio-Rad, Hercules, CA, USA), and each sample was diluted to a protein concentration of $1 \mathrm{mg} / \mathrm{ml}$ with lysate buffer followed by the addition of Laemmli's 5X SDS-sample buffer. Each sample of proteins and prestained molecular weight markers (Gibco BRL) were separated by SDS-PAGE and then transferred to PVDF membranes (Immobilon-P, Millipore, Bedford, MA, USA). The membranes were incubated for $2 \mathrm{~h}$ at $20-22^{\circ} \mathrm{C}$ in a blocking solution for phosphorylated proteins (Blocking One-P, Nacalai Tesque, Kyoto, Japan). Then they were washed briefly in PBS-Tween and incubated overnight at $4^{\circ} \mathrm{C}$ in a blocking solution containing specific antibodies. Next, the membranes were washed 4 times for 30 min with PBS-Tween and subsequently incubated for $1 \mathrm{~h}$ at ambient temperature in 5\% skim milk in PBS-Tween containing horseradish peroxidase-conjugated second antibodies. The membranes were washed again and the interacting proteins were identified using an ECL detection kit (Amersham Pharmacia). To re-use the membrane, the antibody was stripped off by treatment with $2 \%$ SDS and $0.35 \%$ 2-mercaptoethanol in $62.5 \mathrm{mM}$ Tris- $\mathrm{HCl}(\mathrm{pH} 6.8)$ for $30 \mathrm{~min}$ at $50^{\circ} \mathrm{C}$. The antibody stripped-membranes were then blocked again and re-incubated with another appropriate antibody.

In vitro dephosphorylation. Whole cell lysates were prepared from MG63 cells untreated or treated with $2 \mathrm{nM} \mathrm{CA}$. Cell lysates $(10 \mu \mathrm{g})$ were incubated for $60 \mathrm{~min}$ at $30^{\circ} \mathrm{C}$ with $1,000 \mathrm{U}$ of $\lambda$ protein phosphatase (New England BioLabs), a residuenon-specific protein phosphatase, in the reaction buffer. After incubation, 5X SDS sample buffer was added to the reaction mixture, and the proteins were denatured for $5 \mathrm{~min}$ in boiling water. The samples were subjected to SDS-PAGE and analyzed by Western blotting.

DNA construction and transfection. Plasmid pEGFP-p65NF-кB (human) was kindly provided by Dr J.A. Schmid. A phosphorylation site mutation of p65NF-kB S536A (carrying a mutation of serine to alanine at position 536) was introduced by QuickChange II Site-Directed Mutagenesis Kit (Stratagene, La Jolla, CA, USA). The nucleotide sequences were confirmed by DNA sequencing. Transfection was performed with Lipofectamine 2000 system (Invitrogen, Carlsbad, CA, USA). HEK293 cells were plated in $60-\mathrm{mm}$ plastic dishes and maintained in D-MEM containing $10 \%$ FBS until they had reached $70-80 \%$ confluence. Before transfection, the cells were washed once with serum-free medium. DNA $(10 \mu \mathrm{g})$ or Lipofectamine 2000 reagent was mixed with $1.5 \mathrm{ml}$ OPTI-MEM for $5 \mathrm{~min}$. The mixtures were added together, incubated for $30 \mathrm{~min}$ at room temperature, and the complex

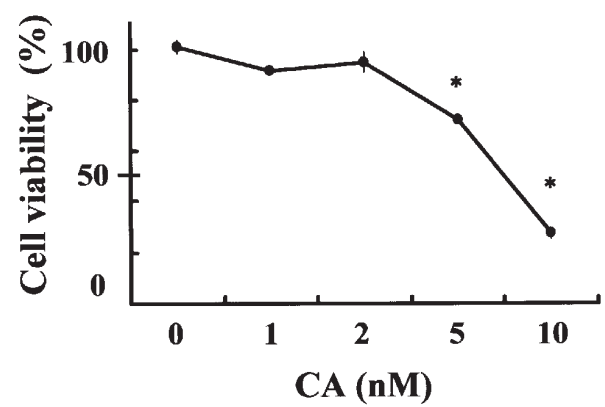

Figure 1. Effects of CA on cell viability in MG63 cells. MG63 cells grown in 96-well plates were treated for $24 \mathrm{~h}$ with various concentrations of CA and the cell viability was determined by the WST- 8 assay. The activity was compared to the control well of the same cell line and results are expressed as a percentage of the control (mean $\pm S E M)(N=3)$. The absorbance at $450 \mathrm{~nm}$ of the control cultures were $0.604 \pm 0.017$. Significant differences from the control cultures are indicated by an asterisk; ${ }^{*} \mathrm{P}<0.01$ (Student's t-test).

was overlaid onto the cells. After incubation at $37^{\circ} \mathrm{C}$ for $4 \mathrm{~h}$, the medium was replaced with fresh D-MEM containing $10 \%$ FBS and incubation was continued for another $24 \mathrm{~h}$ and treated with $\mathrm{CA}$.

\section{Results}

Induction of apoptosis in MG63 cells by CA. Treatment with $0.1 \mathrm{nM}$ CA for $24 \mathrm{~h}$ had a minimal effect on MG63 cell survival as observed under a phase-contrast microscope. Cell rounding and shrinking were obvious in the cultures treated for $24 \mathrm{~h}$ with $5 \mathrm{nM} \mathrm{CA}$. To further quantify the CA-induced cell death in MG63 cells, cytotoxicity was measured by the WST-8 cell viability assay. Fig. 1 shows that CA induced cytotoxicity in MG63 cells in a dose-dependent manner up to $10 \mathrm{nM}$. The level of the cell viability treated with $10 \mathrm{nM}$ CA was $27 \%$ that of the control cultures. To determine if CA-induced cytotoxicity in MG63 cells was due to apoptosis, we evaluated the presence of nuclear fragmentation and condensation in MG63 cells treated for $48 \mathrm{~h}$ with various concentrations of CA. The control cultures of MG63 cells did not show any apoptotic features. However, nucleic acid staining with Hoechst 33342 revealed typical apoptotic nuclei, which exhibited highly fluorescent condensed chromatin in the cells treated with $5 \mathrm{nM} \mathrm{CA}$ (Fig. 2A). The number of the cells with nuclear fragmentation increased in response to $\mathrm{CA}$ in dose- and time-dependent manner (data not shown). In MG63 cells treated for $48 \mathrm{~h}$ with CA, a DNA fragmentation pattern forming a ladder of multiples of 185-200 bp was observed (Fig. 2B). The DNA laddering pattern of the CAtreated cells reached a maximal level at $10 \mathrm{nM}$. The doseand time-dependence of CA-induced DNA ladder formation were comparable to that of the cytotoxicity obtained from WST-8 assay.

Expression of PTEN, FasL, and FasR mRNA in MG63 cells treated with $C A$. We examined mRNA expression of PTEN, FasL, and FasR in MG63 cells treated with 2 nM CA. Approximately 460-, 410-, and 440-bp bands corresponding to PTEN, FasL, and FasR respectively, were detected in MG63 cells treated for $1 \mathrm{~h}$ with $\mathrm{CA}$ after amplification of cDNA for 32 
A

B

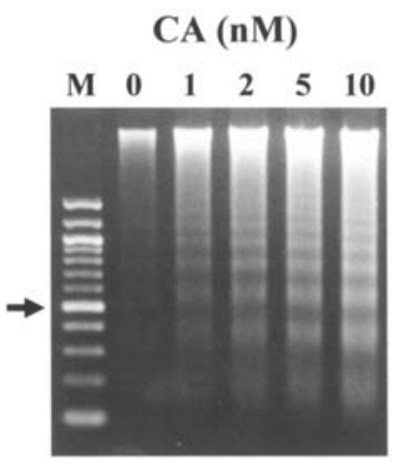

Figure 2. Nuclear fragmentation of MG63 cells treated with CA. (A) Nuclear morphology of MG63 cells treated with CA. MG63 cells were treated for 48 h with $5 \mathrm{nM}$ CA. Cells were stained with Hoechst 33342 and observed under a fluorescent microscope. Bar represents $10 \mu \mathrm{m}$. (B) DNA ladder formation in CA-treated MG63 cells. MG63 cells were exposed for $48 \mathrm{~h}$ to various concentrations of $\mathrm{CA}$ indicated. DNA was extracted and analyzed on an agarose gel. Lane M, standard DNA markers; arrow indicates 500 bp.

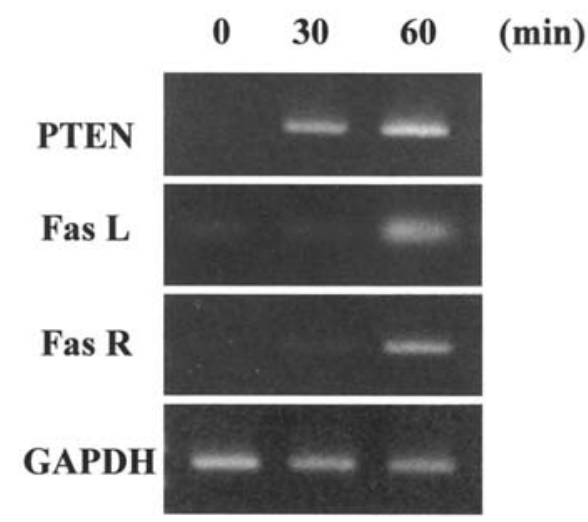

Figure 3. Expression of PTEN, FasL, and FasR mRNA in MG63 cells treated with CA. After having reached confluence, MG63 cells were treated with $2 \mathrm{nM} \mathrm{CA}$ for various time-points indicated and semiquantitative analysis of PTEN, FasL, and FasR mRNA was done with the mRNA amplified by 32 cycles in MG63 cells. The RT-PCR product of GAPDH prepared from the same samples and amplified for 29 cycles is also shown.

cycles. The RT-PCR exponential phase was determined from 30 to 34 cycles to allow semiquantitative comparisons among cDNAs developed from identical reactions. Fig. 3 shows that the expression of PTEN, FasL, and FasR mRNAs in MG63 cells treated with CA increased in a time-dependent manner. The RT-PCR product of GAPDH prepared from the same cells and amplified for 29 cycles is also shown in Fig. 3. The $G A P D H$ mRNA was constitutively expressed, and its level was not affected by CA-treatment (Fig. 3).

Regulation of I $\mathrm{KB} \alpha$ in MG63 cells treated with CA. Whole cell lysates were prepared from MG63 cells treated for various time periods with $2 \mathrm{nM} \mathrm{CA}$. The cells were also treated with $10 \mathrm{ng} / \mathrm{ml} \mathrm{TNF-} \alpha$ for the control. The expression level of IкB $\alpha$ was examined by Western blot analysis by using anti-IкB $\alpha$ antibody. Fig. 4 shows that the anti-IкB $\alpha$ antibody interacted with a protein of $38 \mathrm{kDa}$ in the unstimulated cells. CA treatment decreased the staining intensity of $\mathrm{I} \kappa \mathrm{B} \alpha$ up to $2 \mathrm{~h}$, at which

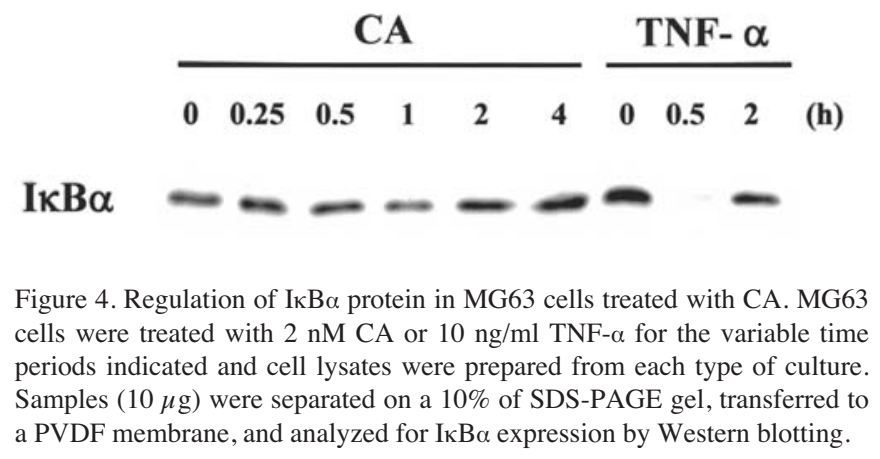

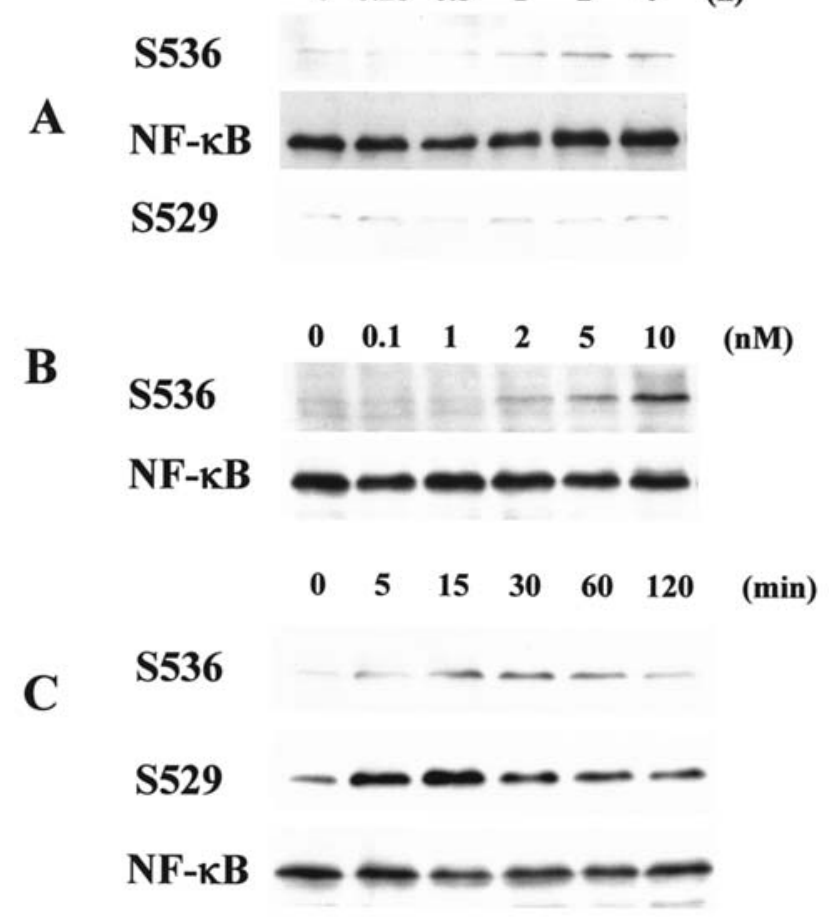

Figure 5. Western blot analysis of phospho-NF-кB in MG63 cells. (A) Cell lysates were prepared from MG63 cells treated with $2 \mathrm{nM}$ for various times indicated. The blotted membrane was incubated with the anti-phospho-

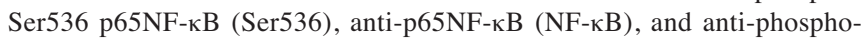
Ser529 р65NF-кB (S529) antibodies. (B) The cells were treated for $3 \mathrm{~h}$ with various concentrations of $\mathrm{CA}$ as indicated. The samples were analyzed by Western blotting using anti-phospho-Ser536 p65NF-кB antibody (S536). The antibody was stripped off the membrane and replaced with anti-p65NF-кB

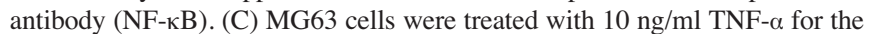
variable time periods indicated, cell lysates were prepared from each type of culture and analyzed by Western blotting by using anti-phospho-Ser536 p65NF-кB (Ser536), anti-phospho-Ser529 p65NF-кB (S529) or anti-p65NF-кB $(\mathrm{NF}-\kappa \mathrm{B})$ antibodies.

time the staining level was minimum, then the staining level increased time dependently up to $4 \mathrm{~h}$. Fig. 4 also shows that I $\mathrm{B} \alpha$ was completely degraded by the TNF- $\alpha$ treatment within $30 \mathrm{~min}$. Then the expression level of IкB $\alpha$ increased by $2 \mathrm{~h}$, at which point the staining was almost at the same level as that of the unstimulated control cells.

Phosphorylation of $N F-\kappa B$ on serine 536 residue by $C A$ treatment. Fig. 5A shows the anti-phospho-Ser536 p65NF-кB 


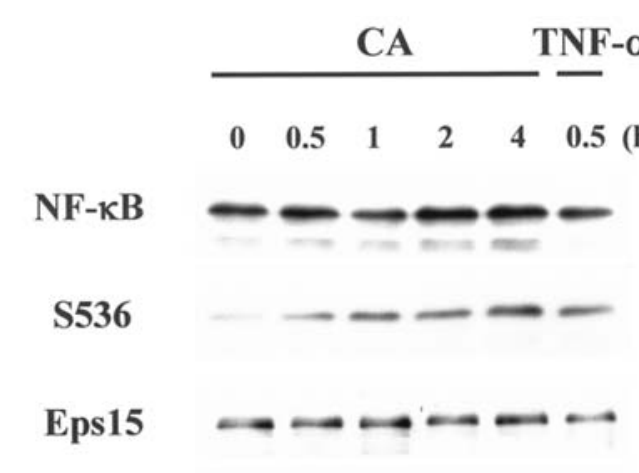

Lamin B1

\section{Cytosol}

\section{Nucleus}

Figure 6. Nuclear translocation of NF-кB in MG63 cells treated with CA. MG63 cells were treated with 2 nM CA or $10 \mathrm{ng} / \mathrm{ml}$ TNF- $\alpha$ for various time-points indicated. Cell fractionation was done to prepare the cytosolic (left panel) and nuclear (right panel) fractions. Proteins prepared from each fraction were subjected

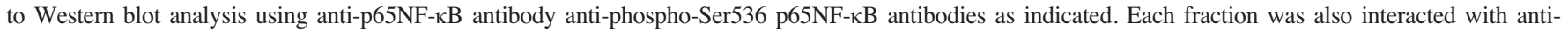
Eps15 and anti-Lamin B1 antibodies to ensure the purity of cytosolic and nuclear fractions, respectively.

antibody interacted with a band having an estimated molecular weight of $65 \mathrm{kDa}$. It appeared after $1-2 \mathrm{~h}$ of CA-treatment, and the level of staining increased up to $4 \mathrm{~h}$ (Fig. 5A, upper panel). The bound antibody was stripped off the membrane and the membrane was re-incubated with anti-p65NF- $\mathrm{B}$ antibody. This antibody recognized a $65-\mathrm{kDa}$ band and the staining intensity was not affected by CA-treatment (Fig. 5A, middle panel). The anti-phospho-Ser529 p65NF-кB antibody also recognized a $65 \mathrm{kDa}$ band (Fig. 5A, bottom panel). However, the level of the staining intensity was not affected by CA-treatment. The anti-phospho-Ser276 p65NF-кB antibody did not react with any proteins (data not shown). Fig. 5B shows the reaction between the anti-phospho-Ser536 p $65 \mathrm{NF}-\kappa \mathrm{B}$ antibody and the proteins extracted from the MG63 cells treated for $3 \mathrm{~h}$ with various concentrations of CA. Staining intensity was weak in the extracts prepared from the untreated control cells. The anti-phospho-Ser536 p65NF- $\mathrm{BB}$ antibody interacted with a $65 \mathrm{kDa}$ band and the intensity of this band increased in a dose-dependent manner up to $10 \mathrm{nM} \mathrm{CA}$. When the bound antibody was stripped off the membrane and re-incubated with anti-p65NF-кB antibody, the staining intensity of this band was not changed. The cells were also treated for various time-points with $10 \mathrm{ng} / \mathrm{ml}$ of TNF- $\alpha$. Fig. 5C shows that anti phospho-Ser536 and antiphospho-Ser529 p65NF-кB antibodies interacted with a protein of $65 \mathrm{kDa}$ at 5 -min treatment and the staining intensity increased up to 60 and $15 \mathrm{~min}$, respectively.

Translocation of $N F-\kappa B$ in MG63 cells treated with $C A$. Cytosolic and nuclear fractions were prepared from MG63 cells treated for various time periods with $2 \mathrm{nM} \mathrm{CA}$ and $10 \mathrm{ng} / \mathrm{ml}$ TNF- $\alpha$. Anti-p65NF- $\kappa$ B antibody recognized a $65 \mathrm{kDa}$ band in the cytosolic fractions of unstimulated or CA-treated cells (Fig. 6). The staining reaction of anti-p65NF- $\mathrm{kB}$ antibody was not detected in the nuclear fraction of the unstimulated cells, however, p65NF- $\mathrm{kB}$ appeared in the nuclear fraction with CA-treatment and the staining intensity increased (Fig. 6). The anti-phospho-Ser536 p65NF- $\mathrm{BB}$ antibody did not react with any proteins in the cytosolic and nuclear fractions of

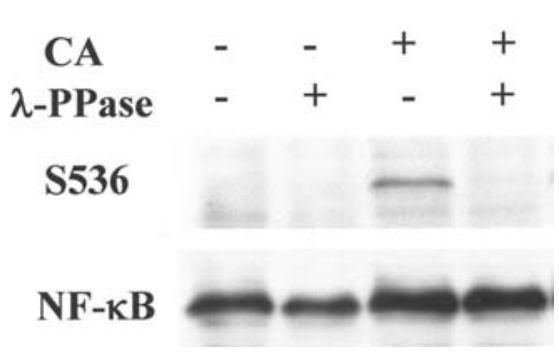

Figure 7. Dephosphorylation of phospho-NF-кB with $\lambda$ protein phosphatase. MG63 cells were untreated or treated for $4 \mathrm{~h}$ with or without $2 \mathrm{nM} \mathrm{CA}$ as indicated. Cell lysates prepared from each type of culture were incubated for $60 \mathrm{~min}$ at $30^{\circ} \mathrm{C}$ with or without 1,000 units of $\lambda$ protein phosphatase ( $\lambda$-PPase) as indicated. The samples were then analyzed by Western blotting by using

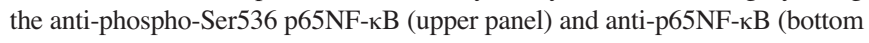
panel) antibodies.

the control cells (Fig. 6). However, the staining intensity of phospho-Ser536 $\mathrm{p} 65 \mathrm{NF}-\mathrm{\kappa B}$ increased both in the cytosolic and nuclear fractions of the cells treated with CA. In the cells treated with TNF- $\alpha$, anti-phospho-Ser536 p65NF-кB antibody reacted with the proteins in the cytosolic and nuclear fractions. The anti-Eps15 antibody interacted with a $140-\mathrm{kDa}$ band in the cytosolic fractions of CA- or TNF- $\alpha$-treated cells while this antibody did not interact with any proteins in the nuclear fractions (Fig. 6). The anti-Lamin B1 antibody did not interact with any proteins in the cytosolic fractions whereas this antibody interacted with a protein of $68 \mathrm{kDa}$ in the nuclear fractions, indicating that cell fractionation in the present study validate the high purity of each fraction.

In vitro dephosphorylation and phosphorylation of mutant gene products. To confirm that the band recognized by the anti-phospho-Ser536 p65NF-кB antibody was the phosphorylated form of $\mathrm{p} 65 \mathrm{NF}-\kappa \mathrm{B}$, we prepared lysates from CAtreated cells and incubated them with $\lambda$ protein phosphatase. Fig. 7 shows that treatment of the cell lysates with $\lambda$ protein phosphatase resulted in the disappearance of the band interacted with anti-phospho-Ser536 p65NF-кB antibody whereas this 


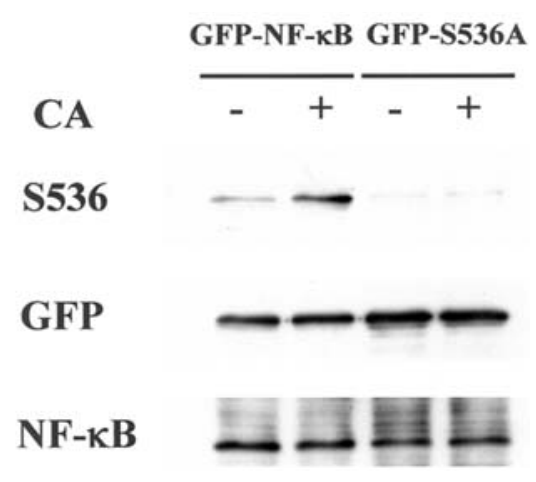

Figure 8. Phosphorylation of NF-kB in the cells transfected with the mutant p65NF-kB. HEK293 cells were transfected with GFP-NF-kB and GFP-S536A plasmid and treated with or without $2 \mathrm{nM} \mathrm{CA}$ as indicated. Cell lysates were prepared from each type of culture and analyzed by Western blotting using the anti-phospho-Ser536 p65NF-kB, anti-GFP, and anti-p65NF-kB antibodies as indicated.

band was retained in the lysates from the untreated control cells. To confirm further that CA could stimulate phosphorylation of Ser536 of $\mathrm{p} 65 \mathrm{NF}-\kappa \mathrm{B}$, we constructed mutant p $65 \mathrm{NF}-\kappa \mathrm{B}$ gene in which the serine at 536 was replaced with alanine (GFP-S536A). We also used GFP-p65NF-кB (GFP-NF- $\mathrm{kB}$ ) as control. The plasmids were transfected into HEK293 cells, cultured with or without CA, and cell lysates were prepared. Fig. 8 shows that the anti-phospho-Ser536 p65NF- $\mathrm{BB}$ did not interact with the cell lysates prepared from the cells transfected with GFP-S536A mutant gene and treated with or without CA. However, the antibody interacted with the cell lysates from the GFP-NF- $\kappa$ B transfected cells and the staining intensity increased with CA-treatment (Fig. 8). The anti-GFP and anti-p65NF- $\mathrm{BB}$ antibodies interacted with the proteins prepared from these cells and the staining intensity did not change with CA-treatment (Fig. 8). These results together with those described above indicate that p65NF- $\mathrm{KB}$ was phosphorylated at serine 536 residue of p65NF- $\kappa \mathrm{B}$ by CA treatment.

\section{Discussion}

In the present study, we treated human osteoblastic MG63 cells with various concentrations of CA for various timepoints to examine whether this inhibitor of protein phosphatases could induce apoptosis in these cells. Under a phase-contrast microscopy, obvious morphological changes were observed in MG63 cells treated with CA. Loss of cell viability in CA-treated cells was demonstrated by the WST- 8 cell viability assay. By using the Hoechst 33342 staining, marked nuclear condensation and fragmentation into spherical bodies were demonstrated. Moreover, DNA ladder formation was detected in MG63 cells treated with CA. These results indicate that CA induced apoptosis in MG63 cells. Effect of CA on induction of apoptosis is not limited to MG63 cells because CA induced apoptosis in human osteoblastic Saos- 2 cells and human squamous carcinoma SCC-25 cells (22-24). Because the expression of PTEN, FasL, and FasR mRNA in MG63 cells increased with CA-treatment, apoptosis would be induced by the apoptosis inducing factors. The induction of cell death genes and ongoing protein synthesis might be needed in CA-induced apoptosis in MG63 cells. It might be possible that PP1 and/or PP2A are responsible for CA-induced apoptosis. Inhibition of protein phosphatase activity by $\mathrm{CA}$ and related substances may be a general way of triggering apoptosis via the cell death inducing genes in some kinds of cells. However, it was reported that new protein synthesis was not required for CA-induced apoptosis (25). Most cells might have machinery by which they commit apoptosis under an inappropriate phosphorylation status. Several reports have pointed to PTEN, FasR, and FasL as important regulators of NF- $\kappa$ B-mediated apoptosis $(9,26)$. Upregulation of PTEN, FasR and FasL by NF- $\mathrm{kB}$ was found to be critical to apoptosis $(18,27)$. Although the expression of apoptosis inducing substances were not examined in detail PTEN or FasR and FasL system should cause the induction of apoptosis in MG63 cells.

We explored the effects of $\mathrm{CA}$ on the phosphorylation status of NF-кB in MG63 cells. We demonstrated that p65NF$\kappa \mathrm{B}$ was phosphorylated on serine residue at position 536 by the CA treatment. The phosphorylation of serine 536 at $\mathrm{NF}-\kappa \mathrm{B}$ was further confirmed by the $\lambda$ protein phosphatase treatment and by using the cells transfected with the mutated

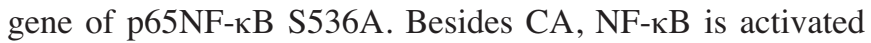
by a wide variety of other agents, including LPS and TNF. Phosphorylation of p65NF- $\mathrm{BB}$ at serine 536 residue by TNF- $\alpha$ becomes evident 5-10 min in MG63 cells demonstrated in the present study. We also demonstrated that TNF- $\alpha$ stimulated phosphorylation of $\mathrm{p} 65 \mathrm{NF}-\mathrm{\kappa B}$ at serine 529 residue within 10 min in MG63 cells. These findings are in good agreement with the past reports concerning their biological effects in other systems (28-30). The CA-mediated phosphorylation of $\mathrm{p} 65 \mathrm{NF}-\kappa \mathrm{B}$ occurs slower than that induced by specific receptors associated with TNF- $\alpha$ or LPS. Unlike TNF- $\alpha$ or LPS, CA penetrates the cell membrane and inhibits the intracellular protein phosphatases, thus promoting phosphorylation of serine 536 on $\mathrm{p} 65 \mathrm{NF}-\mathrm{\kappa B}$. The induced signal transduction pathways should be differing among the agents used. The nature of molecules in the pathways of p65NF- $\kappa \mathrm{B}$ phosphorylation on which CA might have an affect is not clear.

Anti-phospho-Ser536 p65NF-кB antibody interacted with the $65-\mathrm{kDa}$ band, which was also recognized by anti-p65NF-кB antibody. This finding indicates that phosphorylation of this site does not influence the migration of p65NF- $\mathrm{BB}$ when subjected to SDS-PAGE. However, anti-phospho-Ser536

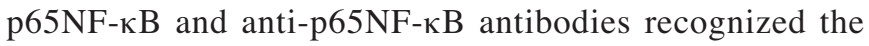
slower migrating band in addition to the $65-\mathrm{kDa}$ band in MG63 cells treated with OA. Because the slower migrating band disappeared on the treatment with $\lambda$ protein phosphatase it should be a super-phosphorylated form of p $65 \mathrm{NF}-\kappa \mathrm{B}$ (unpublished data). Another explanation is that the slower migrating band might be the acetylation form of $\mathrm{p} 65 \mathrm{NF}-\kappa \mathrm{B}$ (31).

The majority of $\mathrm{p} 65 \mathrm{NF}-\kappa \mathrm{B}$ phosphorylation occurs at serine residues, however, only a few phosphorylation sites have been mapped precisely. Phosphorylation of Ser276, situated in the Rel-homology-domain (RHD) in the N-terminus of NF-kB, was reported to be involved in sequence-specific DNA binding, dimerization, and nuclear translocation (32). However, in our study, phosphorylation of Ser276 did not 
occur in MG63 cells by CA or OA treatment, indicating that phosphorylation of Ser276 is not essential for the CA- or OA-activated NF- $\mathrm{kB}$ transcription. Ser536 on $\mathrm{p} 65 \mathrm{NF}-\kappa \mathrm{B}$ was phosphorylated by IKK complex $(28,33,34)$. Over-expression studies with the activated Akt revealed that IKK is necessary for enhanced $\mathrm{p} 65 \mathrm{NF}-\mathrm{\kappa B}$ transactivation, whereas mutation of Ser536 abolishes this effect (34). The involvement of both IKK $\alpha$ and IKK $\beta$ in phosphorylation of Ser536 on p65NF-кB was confirmed by using IKK $\alpha^{-/-}$or IKK $\beta^{-/-}$mouse embryonic fibroblasts (35). In the present study, we demonstrated that CA enhanced the phosphorylation level of Ser536 but not Ser276 and Ser529 on p65NF- $\mathrm{BB}$ in MG63 cells. These findings indicate that phosphorylation of Ser536 on p65NF-кB functions in $\mathrm{NF}-\kappa \mathrm{B}$ activation in the CA-treated cells. In earlier experiments, the phosphorylation of Ser529 on p65NF-кB was shown not to contribute to $\mathrm{NF}-\kappa \mathrm{B}$ activity in response to TNF- $\alpha$ or LPS, suggesting only a minor role for Ser529 phosphorylation on $\mathrm{p} 65 \mathrm{NF}-\kappa \mathrm{B}$ in $\mathrm{NF}-\kappa \mathrm{B}$ function $(28,35)$. As CA enhanced the phosphorylation level of $\mathrm{p} 65 \mathrm{NF}-\kappa \mathrm{B}$, mapping the phosphorylation sites targeted by $\mathrm{CA}$ is quite important to understand how this phosphatase inhibitor functions in the cells. We demonstrated that the translocation of p65NF- $\mathrm{kB}$ from the cytosol to the nucleus was stimulated by $\mathrm{CA}$ treatment. Phosphorylation of Ser536 on p65NF-кB can be detected both in the cytoplasm and nucleus. However, it is unclear if this was due to the shuttling of phosphorylated p $65 \mathrm{NF}-\mathrm{kB}$ or to the presence of Ser536 protein kinase in both the cytoplasm and nucleus $(28,36)$. More detailed experiments are needed to clarify this point.

In response to certain stimuli, I $\mathrm{KB} \alpha$ is phosphorylated, ubiquitinated, and targeted for proteasomal degradation allowing the complex to translocate to the nucleus and bind to $\kappa \mathrm{B}$-response element. One of the target genes of $\mathrm{NF}-\kappa \mathrm{B}$ is its inhibitor $\mathrm{I} \kappa \mathrm{B} \alpha$, resynthesis of which gives rise to an autoregulatory loop that terminates the activation process of NF- $\kappa \mathrm{B}$ (37). In MG63 cells TNF- $\alpha$ stimulated the rapid degradation of $\mathrm{I} \kappa \mathrm{B} \alpha$ and translocation of $N F-\kappa \mathrm{B}$ to the nucleus. Although IкB $\alpha$ was degraded by $\mathrm{CA}$-treatment, it was not completely degraded and the process was slower than that of TNF- $\alpha$. Previously we demonstrated that the degradation of I $\mathrm{KB} \alpha$ did not occur in the OA-treated MG63 cells (38). It has also been reported that phosphorylation of Ser536 on p65NF-кB is not involved in the process leading to $I \kappa \mathrm{B} \alpha$ degradation (37). There is evidence that the phosphatidyl-inositol-3 kinase pathway is involved in IкBindependent regulation of $\mathrm{NF}-\kappa \mathrm{B}$ (39). These findings together with our results indicate that, phosphorylation of $\mathrm{NF}-\kappa \mathrm{B}$ does not depend on $\mathrm{I} \kappa \mathrm{B} \alpha$ degradation in certain type of signal transduction.

Changes in NF- $\mathrm{B}$ transcriptional activity have been attributed to the phosphorylation of $\mathrm{p} 65 \mathrm{NF}-\kappa \mathrm{B}$ by a large variety of kinases in response to different stimuli (40-42). The N-terminal domain of p65NF-кB was shown to be phosphorylated by $\mathrm{PKC}-\zeta(40,41)$. In fact, $\mathrm{PKC}-\zeta$ can directly and efficiently phosphorylate p65NF- $\mathrm{B}$. More importantly, TNF- $\alpha$-induced phosphorylation of $\mathrm{p} 65 \mathrm{NF}-\kappa \mathrm{B}$ was seriously inhibited in PKC- $\zeta^{-1-}$ embryo fibroblasts (41). It should be remembered that the phosphorylation status of $\mathrm{p} 65 \mathrm{NF}-\mathrm{\kappa B}$ is determined not only by kinase activities but also by the interplay of both kinases and phosphatases. Indeed, PP2A is physically associated with $\mathrm{p} 65 \mathrm{NF}-\kappa \mathrm{B}$ in unstimulated melanocytes and is able to dephosphorylate p65NF- $\mathrm{kB}$ after IL-1 stimulation (43).

Gene expression varies in response to different signals $(44,45)$. Different kinases and phosphatase inhibitors may be acting at various stages of the transcription process, including nuclear transport, DNA-binding capacity, and transcriptional initiation or elongation. The phosphorylation of $\mathrm{p} 65 \mathrm{NF}-\kappa \mathrm{B}$ is a process highly regulated by both cell- and stimulus-dependent activating kinases and phosphatases.

\section{Acknowledgements}

We thank Dr Johannes A. Schmid, University of Vienna Medical School, for providing pEGFP-p65NF-кB plasmid. We also thank Mrs. E. Sasaki for her skilful technical assistance. This study was supported in part by a grant from the Grant-in-Aid for Scientific Research from the Ministry of Education, Science, Sports, and Culture of Japan.

\section{References}

1. Arends MJ and Wyllie AH: Apoptosis: mechanisms and roles in pathology. Int Rev Exp Pathol 32: 223-254, 1991.

2. Jacobson MD, Weil M and Raff MC: Programmed cell death in animal development. Cell 88: 347-354, 1997.

3. Cross TG, Scheel-Toellner D, Henriquez NV, Deacon E, Salmon M and Lord JM: Serine/threonine protein kinases and apoptosis. Exp Cell Res 256: 34-41, 2000

4. Karin M: Nuclear factor-кB in cancer development and progression. Nature 441: 431-436, 2006.

5. Leger DY, Liagre B and Beneytout JL: Role of MAPKs and NF- $\mathrm{KB}$ in diosgenin-induced megakaryocytic differentiation and subsequent apoptosis in HEL cells. Int J Oncol 28: 201-207, 2006.

6. Zhang $\mathrm{Z}$ and Rigas $\mathrm{B}$ : NF-кB, inflammation and pancreatic carcinogenesis: NF- $\kappa \mathrm{B}$ as a chemoprevention target. Int J Oncol 29: 185-192, 2006.

7. Aggarwal BB and Takada Y: Pro-apoptotic and anti-apoptotic effects of tumor necrosis factor in tumor cells. Role of nuclear transcription factor NF-кB. Cancer Treat Res 126: 103-127, 2005.

8. Graham B and Gibson SB: The two faces of NF- $\mathrm{KB}$ in cell survival responses. Cell Cycle 4: 1342-1345, 2005.

9. Lamkanfi M, Declercq W, Vanden Berghe T and Vandenabeele P: Caspases leave the beaten track: caspase-mediated activation of NF-кB. J Cell Biol 173: 165-171, 2006.

10. Piva R, Belardo G and Santoro MG: NF-кB: a stress-regulated switch for cell survival. Antioxid Redox Signal 8: 478-486, 2006.

11. Radhakrishnan SK and Kamalakaran S: Pro-apoptotic role of NF-кB: implications for cancer therapy. Biochim Biophys Acta 1766: 53-62, 2006.

12. Scheidereit $\mathrm{C}$ : IкB kinase complexes: gateways to NF-кB activation and transcription. Oncogene 25: 6685-6705, 2006.

13. Viatour P, Merville MP, Bours V and Chariot A: Phosphorylation of NF- $\mathrm{KB}$ proteins: implications in cancer and inflammation. Trends Biochem Sci 30: 43-52, 2005.

14. Perkins ND: Post-translational modifications regulating the activity and function of the nuclear factor kappa B pathway. Oncogene 25: 6717-6730, 2006.

15. Cohen P, Holmes CFB and Tsukitani Y: Okadaic acid: a new probe for the study of cellular regulation. Trends Biochem Sci 15: 98-102, 1990.

16. Suganuma M, Fujiki H, Furuya-Suguri H, Yoshizawa S, Yasumoto S, Kato Y, Fusetani N and Sugimura T: Calyculin A, an inhibitor of protein phosphatases, a potent tumor promoter on CD-1 mouse skin. Cancer Res 50: 3521-3525, 1990.

17. Fernandez JJ, Candenas ML, Souto ML, Trujillo MM and Norte M: Okadaic acid, useful tool for studying cellular processes. Curr Med Chem 9: 229-262, 2002.

18. Fujita M, Goto K, Yoshida K, Okamura H, Morimoto H, Kito S, Fukuda $J$ and Haneji T: Okadaic acid stimulates expression of Fas receptor and Fas ligand by activation of nuclear factor kappa-B in human oral squamous carcinoma cells. Oral Oncol 40: 199-206, 2004. 
19. Haneji T: Association of protein phosphatase 1 delta with nucleolin in osteoblastic cells and cleavage of nucleolin in apoptosisinduced osteoblastic cells. Acta Histochem Cytochem 38: 1-8, 2005.

20. Morimoto H, Okamura H, Yoshida K, Kitamura S and Haneji T: Okadaic acid induces apoptosis through double-stranded RNAdependent protein kinase/eukaryotic initiation factor-2 $\alpha$ pathway in human osteoblastic MG63 cells. J Biochem 136: 433-438, 2004.

21. Ozaki A, Morimoto H, Tanaka H, Okamura H, Yoshida K, Amorim BR and Haneji T: Okadaic acid induces phosphorylation of p65NF-B on serine 536 and activates NF- $\mathrm{\kappa B}$ transcriptional activity in human osteoblastic MG63 cells. J Cell Biochem 99: 1275-1284, 2006

22. Morimoto Y, Ohba T, Kobayashi S and Haneji T: The protein phosphatase inhibitors okadaic acid and calyculin A induce apoptosis in human osteoblastic cells. Exp Cell Res 230: 181-186, 1997.

23. Okamura H, Yoshida K, Sasaki E, Morimoto H and Haneji T: Transcription factor NF-Y regulates $m d r l$ expression through binding to inverted CCAAT sequence in drug-resistant human squamous carcinoma cells. Int J Oncol 25: 1031-1037, 2004.

24. Okamura H, Yoshida K, Morimoto H and Haneji T: PTEN expression elicited by EGR-1transcription factor in calyculin Ainduced apoptotic cells. J Cell Biochem 94: 117-125, 2005.

25. Bøe R, Gjertsen BT, Vintermyr OK, Houge G, Lanotte M and Døskeland SO: The protein phosphatase inhibitor okadaic acid induces morphological changes typical of apoptosis in mammalian cells. Exp Cell Res 195: 237-246, 1991.

26. Tanaka Y, Singh S and Aggarwal BB: Identification of a p65 peptide that selectively inhibits NF- $\mathrm{\kappa B}$ activation induced by various inflammatory stimuli and its role in down-regulation of $\mathrm{NF}-\kappa \mathrm{B}-$ mediated gene expression and up-regulation of apoptosis. J Biol Chem 279: 15096-15104, 2004.

27. Bertram J, Peacock JW, Tan C, Mui AL, Chung SW, Gleave ME, Dedhar S, Cox ME and Ong CJ: Inhibition of the phosphatidylinositol 3'-kinase pathway promotes autocrine Fas-induced death of phosphatase and tensin homologue-deficient prostate cancer cells. Cancer Res 66: 4781-4788, 2006.

28. Yang F, Tang E, Guan K and Wang CY: IKKß plays an essential role in the phosphorylation of RelA/p65 on serine 536 induced by lipopolysaccharide. J Immunol 170: 5630-5635, 2003.

29. Doyle SL, Jefferies CA and O'Neill LA: Bruton's tyrosine kinase is involved in p65-mediated transactivation and phosphorylation of p65 on serine 536 during NFKB activation by lipopolysaccharide. J Biol Chem 280: 23496-23501, 2005.

30. Shiraki K, Yamanaka T, Inoue H, Kawakita T, Enokimura N, Okano H, Sugimoto K, Murata K and Nakano T: Expression of TNF-related apoptosis-inducing ligand in human hepatocellular carcinoma. Int J Oncol 26: 1273-1281, 2005.

31. Chen LF, Williams SA, Mu Y, Nakano H, Duerr JM, Buckbinder L and Greene WB: NF- $\mathrm{kB}$ RelA phosphorylation regulates RelA acetylation. Mol Cell Biol 25: 7966-7975, 2005.
32. Okazaki T, Sakon S, Sasazuki T, Sakurai H, Doi T, Yagita H, Okumura $\mathrm{K}$ and Nakano $\mathrm{H}$ : Phosphorylation of serine 276 is essential for p65 NF-кB subunit-dependent cellular responses. Biochem Biophys Res Commun 300: 807-812, 2003.

33. Sakurai H, Chiba H, Miyoshi H, Sugita T and Toriumi W: IкB kinases phosphorylate NF- $\mathrm{BB}$ p65 subunit on serine 536 in the transactivation domain. J Biol Chem 274: 30353-30356, 1999.

34. Madrid LV, Mayo MW, Reuther JY and Baldwin AS Jr: Akt stimulates the transactivation potential of the RelA/p65 subunit

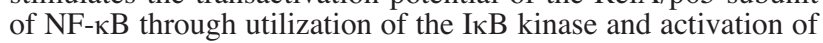
the mitogen-activated protein kinase p38. J Biol Chem 276: 18934-18940, 2001

35. Sizemore N, Lerner N, Dombrowski N, Sakurai H and Stark GR: Distinct roles of the IкB kinase $\alpha$ and $\beta$ subunits in liberating nuclear factor $\kappa \mathrm{B}(\mathrm{NF}-\kappa \mathrm{B})$ from IкB and in phosphorylating the p65 subunit of NF-кB. J Biol Chem 277: 3863-3869, 2002.

36. Sakurai H, Suzuki S, Kawasaki N, Nakano H, Okazaki T, Chino A, Doi T and Saiki I: Tumor necrosis factor- $\alpha$-induced IKK phosphorylation of NF- $\mathrm{KB}$ p65 on serine 536 is mediated though the TRAF2, TRAF5, and TAK1 signaling pathway. J Biol Chem 278: 36916-36923, 2003

37. Sasaki CY, Barberi TJ, Ghosh P and Longo DL: Phosphorylation

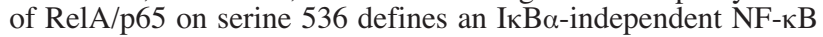
pathway. J Biol Chem 280: 34538-34547, 2005.

38. Morimoto $\mathrm{H}$, Ozaki A, Okamura H, Yoshida K, Kitamura S and Haneji T: Okadaic acid induces tyrosine phosphorylation of I $\kappa \mathrm{B} \alpha$ that mediated by PKR pathway in human osteoblastic MG63 cells. Mol Cell Biochem 276: 211-217, 2005.

39. Sizemore N, Leung S and Stark GR: Activation of phosphatidylinositol 3-kinase in response to interleukin-1 leads to phosphorylation and activation of the NF- $\mathrm{KB}$ p65/RelA subunit. Mol Cell Biol 19: 4798-4805, 1999.

40. Anrather J, Csizmadia V, Soares MP and Winkler H: Regulation of NF- $\mathrm{B}$ RelA phosphorylation and transcriptional activity by p21ras and protein kinase $\mathrm{C} \zeta$ in primary endothelial cells. J Biol Chem 274: 13594-13603, 1999.

41. Leitges M, Sanz L, Martin P, Duran A, Braun U, García JF, Camacho F, Diaz-Meco MT, Rennert PD and Moscat J: Targeted disruption of the $\xi P K C$ gene results in the impairment of the NF-кB pathway. Mol Cell 8: 771-780, 2001

42. Mascat J, Diaz-Meco MT and Rennert P: NF-кB activation by protein kinase $\mathrm{C}$ isoforms and B-cell function. EMBO Rep 4: 31-36, 2003.

43. Yang J, Fan GH, Wadzinski BE, Sakurai H and Richmond A: Protein phosphatase $2 \mathrm{~A}$ interacts with and directly dephosphorylates RelA. J Biol Chem 276: 47828-47833, 2001.

44. Francastel C, Schübeler D, Martin DIK and Groudine M: Nuclear compartmentalization and gene activity. Nat Rev Mol Cell Biol 1: 137-143, 2000.

45. Stenoien DL, Simeoni S, Sharp ZD and Mancini MA: Subnuclear dynamics and transcription factor function. J Cell Biochem Suppl 35: 99-106, 2000. 